COMPETITOR: Jurnal Pendidikan Kepelatihan Olahraga

Volume 13 Number 2 Year 2021

e-ISSN: 2657-0734 \& p-ISSN: 2085-5389

This work is licensed under a Creative Commons Attribution 4.0 International License

\title{
The Knowledge and The Hydration Status of Junior Martial Art Athletes
}

\author{
Ajeng Sindi Tirtasari ${ }^{1^{*}}$, Kunjung Ashadi ${ }^{2}$ \\ ${ }^{1,2}$ Faculty of Sports Science/State University of Surabaya/East Java/Indonesia \\ ${ }^{1,2}$ Street. Lidah Wetan, Surabaya, 60213, Indonesia \\ ${ }^{1}$ ajeng.17060474139@mhs.unesa.ac.id, ${ }^{2}$ kunjungashadi@unesa.ac.id
}

Received: April 10, 2021; Reviewed: May 12, 2021; Accepted: May 15, 2021;

Published: June 19, 2021

\begin{abstract}
The purpose of this study was to determine the adequacy of fluids in the body during training for youth athletes of martial arts. The research method uses descriptive quantitative. Data collection techniques were obtained from urine tests, interviews, and multiple-choice questions on 10 athletes consisting of five male athletes and five female athletes of martial art with maximum age criteria of 18 years. Data analysis techniques used to mean, standard deviation, percentage, graph, normality, and different test Paired Sample T-Test to find out the difference in the mean. Athletes' knowledge of hydration was in the moderate category and there was a significant difference $($ Sig. $<0.05)$ in the average hydration before and after training by the Madiun Regency martial art athletes.
\end{abstract}

Keywords: Hydration; Athletes; Martial Arts.

\section{INTRODUCTION}

The cultural heritage of indigenous Indonesians is very diverse from various parts of the country and which is still developing today, one of which is a sport in the form of the traditional martial art of martial arts originating from the archipelago. This martial art is growing rapidly in various Southeast Asian countries such as Malaysia, Singapore, Brunei Darussalam and Thailand (Ediyono and Widodo, 2019). The meaning of 2 words, namely martial and arts, where pencak means a movement in the form of a beautiful move by avoiding, on the other hand, silat means a self-defence movement with deflecting techniques, fighting by attacking and locking. In Southeast Asia itself, it is better known as silat, but in Indonesia, it is better known as a martial art (Kumaidah, 2016).

The development of martial arts in Indonesia has spread widely in various islands. It is proven that there are various kinds of hermitage, colleges or martial art organizations in Indonesia and each college or organization has its character and history which over time has developed and has entered various competitions in various countries (Pratama 
The Knowledge And The Hydration Status Of Junior Martial Art Athletes

and Trilaksana, 2018). Martial arts is an achievement sport that is in demand at various age levels ranging from children, young people, adults to the elderly (Ihsan et al, 2018).

Martial arts sports are categorized into four groups, namely sparring, single doubles and teams. A fighting group is a group that matches two fighters from opposite angles. The two fighters carried out attack and defence movements to get points. A single group is a fighter who displays standard single moves properly and correctly according to the rules. The dual group is two fighters from the same camp presenting a planned movement. A squad group is a group featuring three fighters from the same camp performing standardized moves. The time needed for single, double and team groups is 3 minutes, while the competing group takes 1.5 minutes for adolescents, 2 minutes for adults, with a rest time of 1 minute and lasts 3 rounds (IPSI National Conference, 2012).

Martial arts has competed for both at the national and international levels. Excellent physical condition is very important to support an athlete's performance. Every individual who chooses to become an athlete, of course, want an achievement. In a competition, the achievement is the goal of an athlete is participating in a sports competition. To achieve the feat they want, they need to train hard and give their best. Therefore, they must have sufficient physical condition to achieve the achievements they are targeting (Sartono and Firman, 2020).

Physical condition plays an important role in the sport of martial arts. To get optimal performance, an athlete must be able to master techniques, mental, intrinsic and extrinsic motivation and other bio motor components. The training program determines the success rate of an athlete to achieve achievement in compiling a training program that requires precision and accuracy following the training periodization to increase the functional ability of the body's systems. (Wardoyo, 2017).

Bompa and Buzzichelli, 2015) explain that to obtain optimal performance for factors main are needed, namely training, such as physical preparation, technical preparation, tactical preparation, mental preparation. So physical preparation is a component that is quite important to achieve maximum performance for the achievement of an athlete, and nutritional needs are very important for an athlete to get the desired performance. Water is very important for the needs of the body. Water is also an important nutrient for the health of the body because water acts as a lubricant, a temperature-carrying solvent and a provider of minerals and electrolytes in the body. Every human being's water needs also vary depending on age, sex, activity and lifestyle. Therefore, adequate fluid is very important to support metabolism in the body 
(Krisnawati, 2016). (Ashadi, 2015) states that hydration is the adequacy of fluids in the body to maintain and stabilize blood flow, lubricate joints and body tissues, facilitate the digestive process and so on. In our body, $70 \%$ of it is liquid food from which water is very influential in stabilizing the components in the body. Meanwhile, dehydration is a lack of fluids in the body which results in the function of the body's organs not running optimally so that it can cause the body temperature to increase rapidly, it is difficult to concentrate and tire quickly.

Other research states that excess fluid excretion will affect the concentration of athletes (Penggalih et al., 2016). When doing physical activity the body temperature will increase or decrease and the body will adjust or balance so that the body temperature conditions remain normal (Trong et al., 2015). The lack of consuming fluids will have an impact on the health of the body and make the body's performance heavier. Therefore, athletes are expected to meet their fluid needs when doing sports activities so that the body does not become dehydrated (Rismayanti, 2014).

Based on the description that has been described above, it can be seen that there is a gap in this study, which can be obtained from the fact that the majority of athletes still do not understand the importance of knowledge about maintaining body hydration either before or after doing training activities or competitions (Dien Putriana, 2016). Ideally, athletes should maintain adequate water conditions in the body to avoid dehydration, but there is insufficient data to support this research. The problem in this research is that no research raises the case of knowledge and hydration status, especially in the Madiun Regency martial arts athletes, so that to solve problems like this, research is needed to obtain field facts. The novelty of this research lies in the research subject, namely the Madiun Regency martial arts athletes and this research was conducted during the Covid19 pandemic. This research is important to do to determine the hydration status of the Madiun district martial arts athletes. In addition, athletes also provide knowledge of the impact of lack of fluids on the body. So that athletes and coaches can understand and pay attention to training and competing.

\section{METHOD}

The research approach method used quantitative descriptive. The research design used a one-shoot study where data collection took place once a day. The research data were obtained from urine tests, multiple test questions and interviews with 10 athletes 
consisting of 5 male athletes and 5 female athletes of martial arts, Madiun Regency. The research was conducted at Taman Regal Jaya, Madiun Regency.

To determine the hydration status of athletes, urine collection will be carried out before and after the exercise. The exercise starts at 15.00 WIB. The activities carried out are 12 minutes of jogging, $40 \mathrm{~m} 5$ reps 2 sets of sprints, and 20 meters 2 reps 1 set. Exercise lasts 1 hour during the training process athletes are allowed to drink without having to wait for thirst. After completing the training, athletes are given a rest period of 2 minutes and then the urine is collected after the exercise.

Measurement of urine colour before and after exercise used urine colour indicators, while for knowledge about hydration, 20 validated multiple-choice questions were given and each question had a score of 5 and an oral interview was conducted as support. The data analysis technique used the mean, standard deviation, percentage, normality graph, and Paired Sample T-Test with the IBM SPSS version 24 and Microsoft Excel version 2010 analysis tools.

Measurement of knowledge in Madiun district martial arts uses multiple-choice questions totalling 20 questions, which Each question has a score of 5 points, the wrong answer is 0 . The results of each respondent's score can be seen in Table $\mathbf{1}$.

Tabel 1.

Table Qualification Value of Athlete's Knowledge About Hydration

\begin{tabular}{|c|c|c|}
\hline No & Value & Qualification \\
\hline 1 & $0-20$ & Very Less \\
\hline 2 & $21-41$ & Less \\
\hline 3 & $41-60$ & Enough \\
\hline 4 & $61-80$ & Good \\
\hline 5 & $81-100$ & Very Good \\
\hline
\end{tabular}

Measurement of the hydration level uses a colour indicator urine. If the body is well hydrated, the colour of the urine tends to be clear and bright. This is indicated by the colour indicator nos. 1 to 3 , and if the body fluids are not properly hydrated, the colour of the urine tends to be thick and dark yellow as shown by the urine colour indicator nos. 4 to 6 , and on the colour indicator urine 7 to 8 , the body has a lack of fluids that tend to have urine dark yellow and dark colour. 


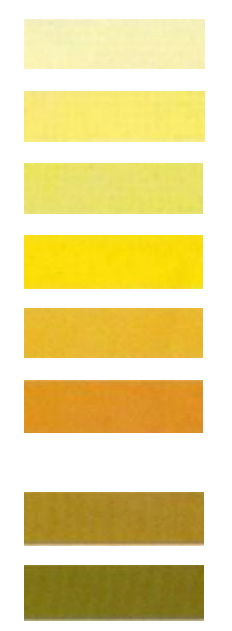

: Well-hydrated category I

: Well-hydrated category II

: Well-hydrated category III

: Moderate Level: not a hydrated well category I

: Moderate Level: not a hydrated well category I

: Moderate Level: not hydrated good category III

: Weight level: not a well-hydrated category I

: Weight level: not well-hydrated category II

\section{Picture 1.}

Color Indicator Urine (Medicastore.com. 2013)

Source:http://medicastore.com/images/world-kidney06.jpg

\section{RESULTS AND DISCUSSION}

Based on the results of research data that has been carried out using urine tests, interviews, and multiple-choice test questions on martial arts athletes in Madiun Regency, the following profiles are obtained. According to Diagram 1 in this study using 10 samples of Madiun district martial arts athletes consisting of $5(50 \%)$ female athletes and $5(50 \%)$ male athletes.

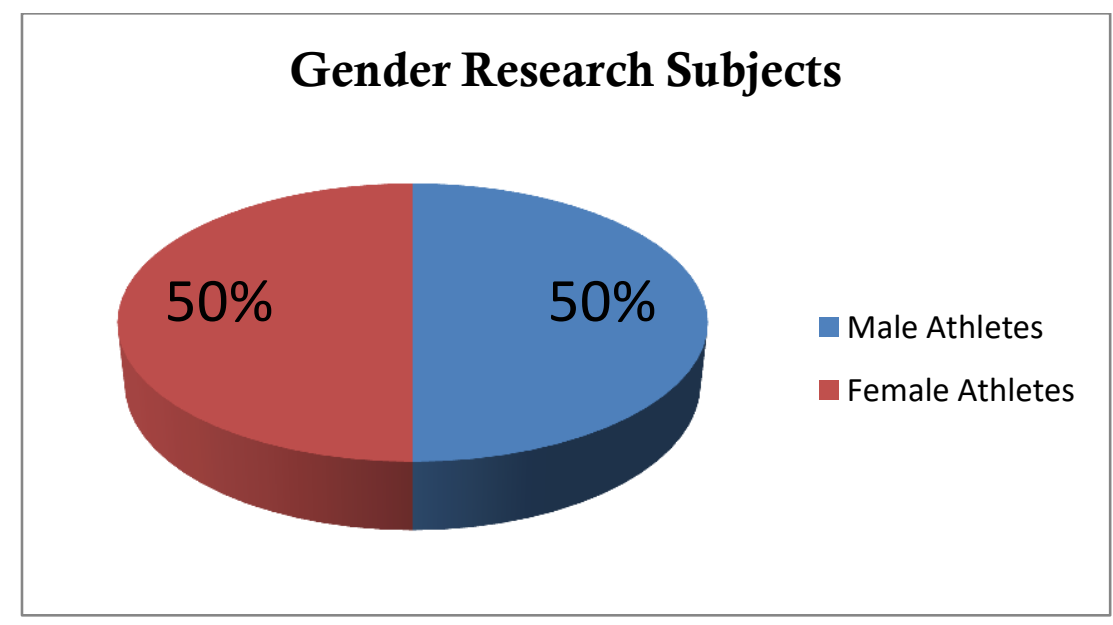

\section{Diagram 1.}

Gender Research Subjects

Descriptive test results obtained from research profiles in which there are profile information age, height and weight of study subjects can be explained in Table 2. 
Table 2.

Table Profile Research Subjects

\begin{tabular}{cccc}
\hline & Age & Height Body & Weight Body \\
\hline Mean & 16.60 Year & $160.00 \mathrm{Cm}$ & $48.40 \mathrm{Kg}$ \\
Standard Deviation & 1,075 Years & $5,164 \mathrm{Cm}$ & $3,718 \mathrm{Kg}$ \\
Minimum & 14 Years & $155 \mathrm{Cm}$ & $40 \mathrm{Kg}$ \\
Maximum & 18 Years & $170 \mathrm{Cm}$ & $53 \mathrm{Kg}$ \\
\hline
\end{tabular}

In addition to the information in Diagram 1, there is also the profile data of research athletes presented in Table 1 with the average age of the research subjects having a range of 14 to 18 years. with a mean age of \pm 16 years. There is also a description of the average height $\pm 160 \mathrm{~cm}$ subjects and the average weight $\pm 48 \mathrm{~kg}$ which if counted will get a body mass index (BMI) athletes $18.91 \mathrm{Kg} / \mathrm{M} 2$, which means normal. Tabel 3.

Table 3.

Average Value And Athlete's Knowledge Category About Hydration

\begin{tabular}{cc}
\hline \multicolumn{2}{c}{ Statistics: Knowledge } \\
\hline Mean & 49.00 \\
Standard Deviation & 13.904 \\
Minimum & 25 \\
Maximum & 75 \\
\hline
\end{tabular}

Based on Table 3 it can be explained that the test results of multiple-choice questions show that 7 athletes are in the sufficient category, 2 athletes are in the poor category, and 1 athlete is in a good category. On the average (mean) results obtained 49.00, which means that the qualification value of knowledge is in the sufficient category.

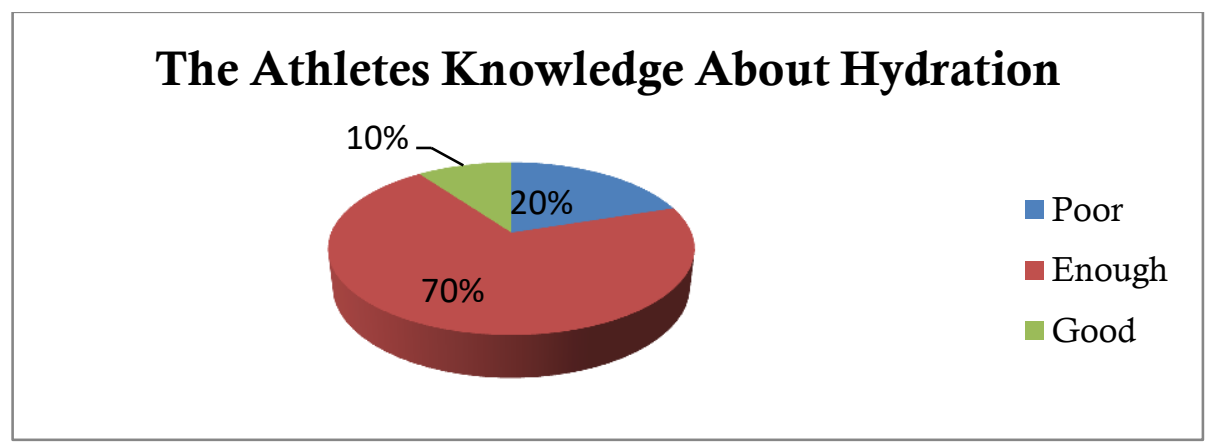

\section{Figure 2.}

Athlete's Knowledge Diagram about Hydration

The average score of athletes' knowledge about hydration is not only described in Table 3, but also for details, it can be noted in Figure 2. Which explains as many as $70 \%$ of respondents have good knowledge of hydration. 
Explanation of the average hydration value of athletes before training can be seen in Table 4, where these results are obtained after testing the urine colour of each study subject.

Table 4.

Average Hydration Value of Athletes Before Exercise

\begin{tabular}{lcc}
\hline & Frequency & Percent \\
\hline Less hydrated well category I & 1 & 10.0 \\
Well-hydrated category I & 3 & 30.0 \\
Well hydrated category II & 2 & 20.0 \\
Well hydrated category III & 4 & 40.0 \\
\hline \multicolumn{1}{c}{ Total } & 10 & 100.0 \\
\hline
\end{tabular}

Based on table 410 athletes took the urine test before training. And it can be seen that 1 athlete is a less well-hydrated category I, 3 athletes are hydrated category I, 2 athletes are hydrated well well category II, and 4 athletes are well category III.

Table 5.

The hydration level category of athletes before training

\begin{tabular}{ll}
\hline Mean & 2.3000 \\
Standard Deviation & 1.05935 \\
Minimum & 1.00 \\
Maximum & 4.00 \\
\hline
\end{tabular}

In the results of Table 5, the average result is 2.30 , which means that the average category value of the athlete's hydration level before training is in the well-hydrated category II with a standard deviation of 1.059 , which means the standard deviation value is smaller than the average hydration. For more details, the analysis of this hydration level can be explained in Diagram 3 as follows.

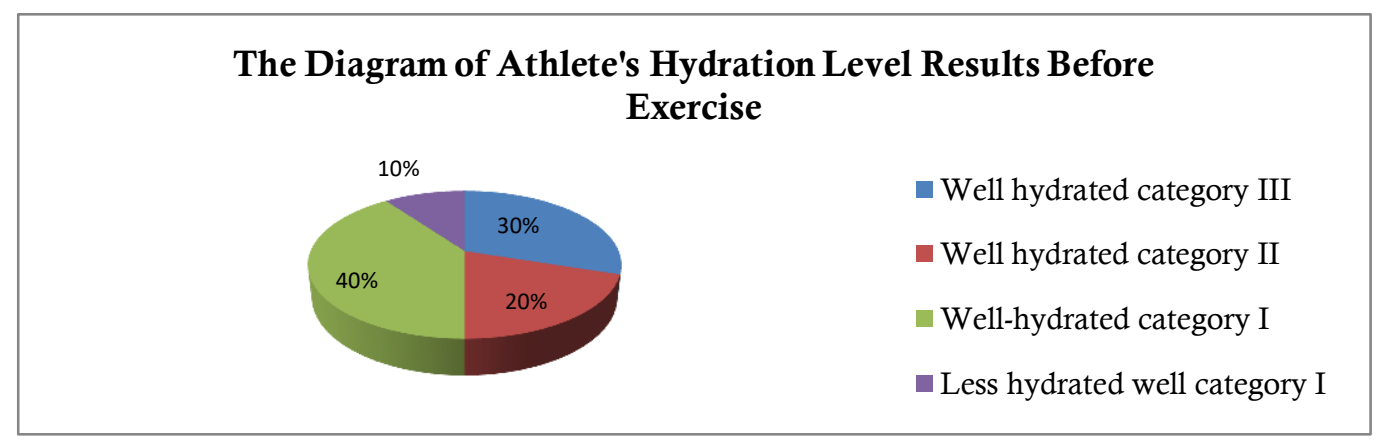

Figure 3.

Diagram of Athlete's Hydration Level Results Before Exercise

An explanation of the average hydration value after exercise can be seen in Table 6 , where these results are obtained after testing the urine colour of each of them. Research subjects. 
Table 6.

Average Hydration Value of Athletes After Exercise

\begin{tabular}{lcc} 
& Frequency & Percent \\
\hline Moderate Level: not a hydrated well category I & 6 & 60.0 \\
Well-hydrated category I & 2 & 20.0 \\
Well-hydrated category II & 1 & 10.0 \\
Well hydarted category IIIs & 1 & 10.0 \\
\hline \multicolumn{1}{c}{ Total } & $\mathbf{1 0}$ & $\mathbf{1 0 0 . 0}$ \\
\hline
\end{tabular}

Based on Table 6 it is known that there are 10 athletes of martial arts in Madiun district who have taken urine tests after training, in the table above it can be seen that 6 athletes are less well-hydrated category I, 2 athletes are well-hydrated category I, 1 athlete is well-hydrated category II and 1 athlete Well-hydrated category III.

Table 7.

Categories of Athlete's Hydration Level After Training

\begin{tabular}{ll}
\hline Mean & 3.1000 \\
Std. Deviation & 1.28668 \\
Minimum & 1.00 \\
Maximum & 4.00 \\
\hline
\end{tabular}

In the results of Table 7 , the average (mean) is 3.10, which means that the average hydration level category of athletes after training is in the well-hydrated category, category III. For more details, the analysis of the hydration level after exercise can be explained in Diagram 4 as follows.

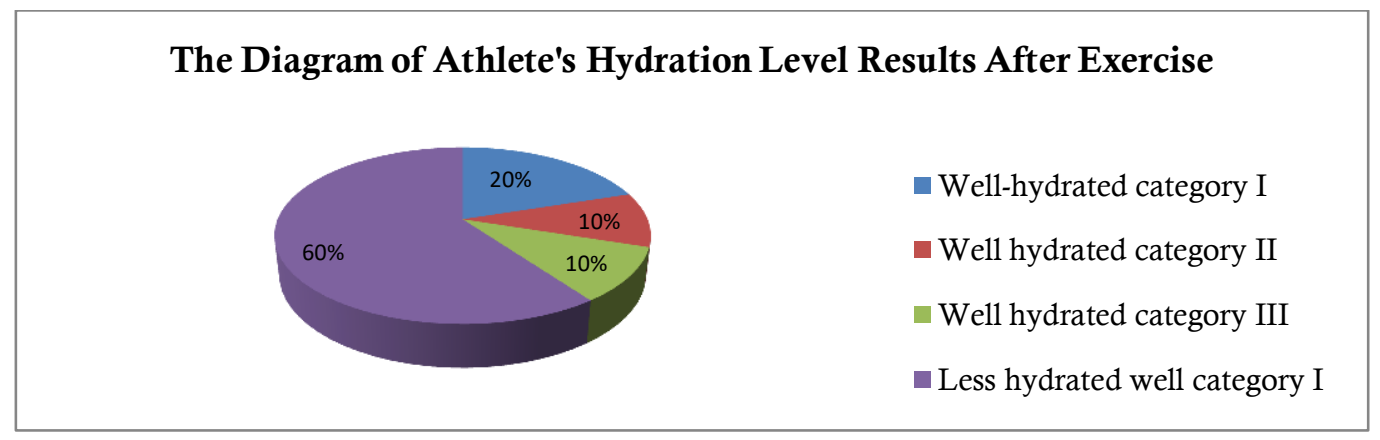

Figure 4.

Diagram of Athlete's Hydration Level Results After Exercise

To analyze an athlete's hydration, a paired difference test or paired t-test is needed, which must be proven that the processed data must be distributed normally. Following are the results of testing normally distributed data using the Kolmogorov-Smirnov method which can be presented in Table 8 . 
The results of table 8 show that the Sig value is $0.200>0.05$, which means that the normality test using the Kolmogorov-Smirnov method shows normally distributed data. Thus, the regression model with the pairwise difference test has been fulfilled.

Table 8.

Data Normality Test

\begin{tabular}{lll}
\hline Information & Value of & Results \\
\hline Asymp. Sig. (2-tailed) & $.200 \mathrm{c}, \mathrm{d}$ & Normal \\
\hline
\end{tabular}

After the requirements are met, to calculate the mean hydration level before and after training, it can be seen that the difference between the hydration level before and after training can use the paired t-test as shown in Table 9.

Table 9.

Paired Samples Statistics

\begin{tabular}{lcc}
\hline & Mean & Std. Deviation \\
\hline Pre Test & 2.3000 & 1.05935 \\
Post Test & 3.1000 & 1.28668 \\
\hline
\end{tabular}

In the results of Table 9, the average test results of the two samples studied were obtained, namely the level of hydration before and after exercise. For values before the mean hydration level was 2.30 . Whereas for the pre-exercise value, the mean hydration level was 3.10. The number of martial arts athletes in the Madiun district used as research samples was 10 athletes with a standard deviation value of 1.05935 pre-test and 1.28668 in the post-test. For more details, it can be in Figure 5 which illustrates the hydration level before and after exercise as follows:

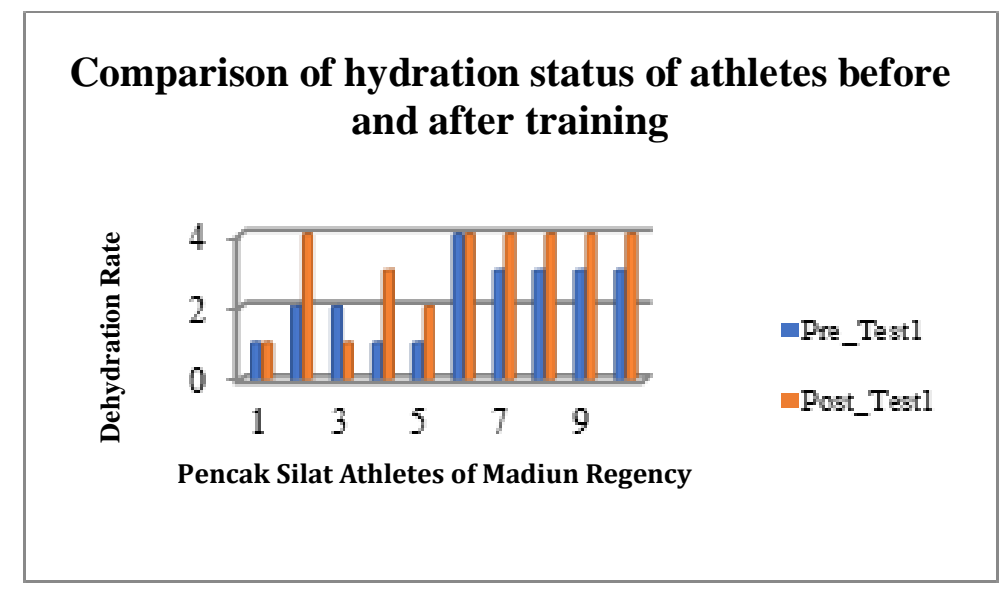

\section{Diagram 5.}

Diagram of Difference in Hydration Levels Before and After Exercise

The mean value in Table 9 is obtained before $2.30<$ after 3.10 , so it can be explained that there is a difference in the mean level of hydration between before and 
The Knowledge And The Hydration Status Of Junior Martial Art Athletes

after exercise. Furthermore, the difference test was carried out by using the paired-sample t-test in Table 11. The results of table 10 show the results of the correlation test on the two data, namely before training with after training of 0.709 with a Sig value. amounting to 0.022 where the Sig. $0.022<0.05$, which means that there is a relationship between the variables before training and the variables after training.

Table 10.

Paired Samples Correlation

\begin{tabular}{lcccc}
\hline & & Correlation & Sig. & Information for \\
\hline Pair1 & PreTest \& PostTest & .709 & .022 & There is a difference \\
\hline
\end{tabular}

In the results of Table 11, it shows that there is a difference in the average difference in the hydration level of male and female athletes before and after training, the significant value is $0.022<0.05$, which means that there is a difference in the mean level of water adequacy. in the body (hydration) in Madiun district martial art athletes before and after training.

Table 11.

Paired Samples Test

\begin{tabular}{cccccccc}
\hline & & Mean & SD & t & df & Sig. & Description \\
\hline Pair 1 & PreTest - PostTest & -0.80000 & 0.91894 & $-2,753$ & 9 & .022 & Significant \\
\hline
\end{tabular}

Test results on a sample mean value test of -0.800 . This value shows the difference between the mean hydration level before exercise with the mean hydration level after exercise or $2.30-3.10=-0.800$. In addition, it is known that the $t$-count is negative, which is -2.753 because the mean value of the hydration level before exercise is lower than the mean level of hydration after exercise.

Based on the data from the calculation of the average hydration level before exercise, the result is 2.30 and after exercise, the result is 3.10 , which means that the hydration status after exercise is one level higher than before the exercise.

There is a significant difference (Sig. <0.05) in the mean value of the hydration level of the Madiun district martial art athletes before and after training. These results indicate that the hydration level before exercise is 1 level better than after exercise.

These results were obtained with the conditions when the training started at 15.30WIB, training during the test was included in the physical exercise group, namely 12 minutes of jogging, $40 \mathrm{~m} 5$ reps 2 sets of sprints, and 20 meters 2 reps 1 set and 1 -hour training. If an athlete is hydrated, it will greatly affect his performance. Based on the data 
The Knowledge And The Hydration Status Of Junior Martial Art Athletes

from the calculation of the average hydration level before the results were 2.30, while after exercise the results were 3.10 , which means that the results were obtained that the hydration level was one level higher than before the exercise. It can be interpreted that an athlete who cannot maintain the balance of fluids in his body, then the athlete cannot give his best performance, and cannot achieve maximum performance results. So an athlete must keep his body hydrated during training so as not to become dehydrated.

Based on the results of the research, there is sufficient knowledge about the importance of maintaining optimal body hydration before and after exercise. The athletes were Madiun district obtained before the good category II hydrated training, while after the training, the results obtained were good hydrated in category III. This can be further improved by socializing the importance of knowledge and awareness of hydration for athlete's performance. The results of this study are in line with (Mahyuni, 2018) with the results at the training stage that they have understood hydration. Before training, athletes belong to the hydrated group, while after training, athletes belong to the dehydrated group. Seeing from the results of urine checks on martial art athletes, it is not fulfilled and has decreased which causes the body's condition to be not optimal because when doing sports activities all organs in the body will experience changes that will cause dehydration.

Hydration is the standard requirement for water in the human body which is useful as a support for metabolism in the body such as stabilizing blood flow, lubricating joints and body tissues, facilitating the digestive process and so on. If the human body is not properly hydrated, it will reduce the level of performance of the athletes in training or competing and this will be detrimental to the athletes, team and supporters. Dehydration is a lack of fluids in the body which causes the function of the organs in the body to not run optimally so that it can cause the body temperature to increase rapidly, it is difficult to concentrate and tire quickly. Therefore, excess fluid excretion will affect the athlete's concentration (Ashadi, 2015).

Many athletes become dehydrated when they start training. Athletes must start learning to assess their hydration needs and they must also take into account each individual's sport, environment and needs. Changes in hydration status during exercise can be estimated from changes in body mass, sweat levels can also be used as a measure to determine the level of hydration.

When doing sports activities, all systems in the bodywork and experience physiological changes that can cause dehydration, athletes should always maintain good 
The Knowledge And The Hydration Status Of Junior Martial Art Athletes

hydration because during sports activities athletes are not aware that the body will lose electrolyte fluid and water simultaneously (Ashadi, 2015).

There are several ways that athletes can keep their bodies hydrated properly, namely by consuming certain foods or drinks, socialization carried out by this sport which explains the importance of keeping the body hydrated. Several ways to prevent the body from decreasing the level of hydration by consuming food or drink are carried out by (Rismawati, Damayanti and Imanudin, 2018) who say that giving watermelon juice and isotonic drinks during exercise can prevent dehydration and maintain hydration status in athletes.

Meanwhile, according to (Dieny and Putriana, 2016) states that there is a relationship between before and after the training of youth soccer athletes. The results of this study indicate that consuming fluids are less able to replace fluids during training or competition. Lack of consuming fluids will cause the risk of dehydration in athletes. It is better if, during training, athletes do not wait for thirst but do appropriate drink arrangements before during after training to maintain body fluids and athlete's performance.

There is a suggestion that reads "The amount of fluid consumption recommended by the institute of medicine for male athletes is 19-20 glasses per day, equivalent to 4.75 litres - 5 litres per day, while for female athletes approximately 14-15 litres. per day is equivalent to 3.5-3.7 litres per day". Therefore, an athlete must consume more fluids than ordinary people (Wicaksono, Margono and Nasuka, 2019). Martial art athletes are not fulfilled and experience a reduction which causes the body's condition to be not optimal because when doing sports activities all organs in the body will experience changes that will cause dehydration (Mahayuni, 2018) The importance of awareness of athlete's hydration and knowledge has a good impact on athlete's activities this means that if athletes are given high-intensity training, they are unlikely to become dehydrated (Fachri, 2017). Athletes who have understood the importance of maintaining fluids in the body with their good knowledge and awareness can regulate water balance for maintaining health and maintaining health in the body. (Qolbi, 2017) Meanwhile, if the athlete has insufficient knowledge, it will have an impact on the performance results of the athlete both before carrying out a training session/competing or after doing training/competing. 


\section{CONCLUSIONS AND SUGGESTIONS}

\section{Conclusions}

The average value of the hydration knowledge martial athletes is of Madison's Arts 49.00, including in the moderate category; The average value of the hydration level of Madison's martial arts athletes before training is 2.30 , which means that it can be categorized as well hydrated category II; The average value of the hydration level of Madiun's martial arts athletes after training is 3.10 , which means that it can be categorized as well hydrated category III; and the average value of the athlete's hydration level after training is in the well-hydrated category III and the results show that the hydration level after training increases by 1 level than before the exercise.

\section{Suggestions}

It is hoped that it can be used as a reference for coaches and athletes to pay more attention to the importance of always maintaining the athlete's body condition so that it is always hydrated in good condition by drinking water during training or competing to provide hydration for athletes. And the importance of knowing the adequacy of fluids in each body to avoid dehydration during sports activities.

\section{REFERENCES}

Ashadi, K. (2015) 'The importance of hydration for athletes.

Bompa, T. and Buzzichelli, C. (2015). Periodization Training for Sports-3rd Edition.

Dieny, FF and Putriana, D. (2016) 'Hydration status before and after youth soccer athlete training', Jurnal Gizi Indonesia (The Indonesian Journal of Nutrition), 3 (2), pp. 86-93. https://doi.org/10.14710/jgi.3.2.86-93.

Ediyono, S. and Widodo, ST (2019) 'Understanding the Meaning of Art in Martial art', Stage, 29 (3). http://dx.doi.org/10.26742/panggung.v29i3.1014 .

Fachri, RL (2017) 'Knowledge of Hydration Awareness in Soccer Athletes SSB Hizbul Wathan U-17, Babat District, Lamongan Regency', Joumal of achievement Sports, 1 (1).

Ihsan, N., Sepriadi and Suwirman (2018) 'Keywords: Nutritional Status, Physical Condition, Achievement Motivation, pp. 410-422.

Krisnawati, D. (2016) 'The Influence of Brand Awareness on the Purchase Decision of Aqua Brand Drinking Water Supply (Study on Society in Bandung)', Journal of ManagementBisnisKrisnadwipayana, 4 (1)http://dx.doi.org/10.35137/jmbk.v4i1. 30.

Kumaidah, E. (2016) 'Strengthening the Nation's Existence through the traditional Martial art Martial Arts'. https://doi.org/10.14710/humanika.16.9. 
Kusumawardani, M. (2017) 'Analysis of Dehydration Levels of Madiun City Pplpd Martial art Athletes, State University of Surabaya', Journal of Sports Achievement, 2 (1). Mahyuni, Aprilia Raditya (2018) 'Hydration Profiles of Martial art Athletes at Pusat Kab Bangkalan Regency in Training Sessions', pp. 1-8.

IPSI National Conference (2012) 'Regulations of signalling', p. 40.

Digger, MHST et al. (2016) 'Fluid Intake and Hydration Status Affect Blood Pressure Profiles in Youth Football Athletes', 39 (2), pp. 93-102. http://dx.doi.org/10.36457/gizindo.v39i2.212 .

Qolbi, APG (2017) 'Comparison of Knowledge About Hydration Awareness in Women's Volleyball and Floorball, State University of Surabaya', Student SmesJournal of Sports Achievement, (Uk M), pp. 1-7.

Rismawati, LH, Damayanti, I. and Imanudin, I. (2018) 'Comparison of the Effects of Giving Watermelon Juice and Isotonic Drinks on the Hydration Status of Futsal Athletes', Journal of Applied Sports Science, 3 (1), p. 67. https://doi.org/10.17509/jtikor.v3i1.11283.

Rismayanti, Sarika (2014) 'Teaching Materials for Dehydration Sports Nutrition', journal of sport, 66, pp. 37-39.

Sartono and Firman, A. (2020) 'The Effect of High-Intensity Interval Training on Physical Conditions in Martial art Athletes https://doi.org/10.33222/juara.v5i1.939.

Trong, TT et al. (2015) 'Ingestion of a cold temperature/menthol beverage increases outdoor exercise performance in a hot, humid environment', PLoS ONE, 10 (4), pp. 1-11. https://doi.org/10.1371/journal.pone.0123815 .

Wardoyo, H. (2017) 'Profile of the Physical Condition of the National Martial art Indonesia Team 2017', Proceedings of the Seminar on FIK UNJ, 2 (1), pp. 111- 116.

Wicaksono, BR, Margono and Nasuka (2019) 'Journal of Sports Coaching and Physical Education Survey Of Dehydration Status And Liquid Consumption After Training On Athletes And Pra Porprov Pre Porprov, Groboan Ku District 20 the Year 2019', 4 (2), pp. 125-131.

Yulio Pratama, R. and Trilaksana, A. (2018) 'Development of the Indonesian Martial art Association (IPSI) 1948-1973', Avatara, 6 (3). 